Tropical Journal of Pharmaceutical Research February 2017; 16 (2): 371-378

ISSN: $1596-5996$ (print); 1596-9827 (electronic) (c) Pharmacotherapy Group, Faculty of Pharmacy, University of Benin, Benin City, 300001 Nigeria.

\title{
Anti-proliferative effect of Moringa oleifera Lam (Moringaceae) leaf extract on human colon cancer HCT116 cell line
}

\author{
Jintana Tragulpakseerojn ${ }^{1,2}$, Naoto Yamaguchi ${ }^{2}$, Perayot Pamonsinlapatham ${ }^{3}$, \\ Penpun Wetwitayaklung ${ }^{4}$, Tatsuro Yoneyama ${ }^{5}$, Naoki Ishikawa ${ }^{5}$, Masami \\ Ishibashi ${ }^{5}$ and Auayporn Apirakaramwong ${ }^{1 \star}$ \\ ${ }^{1}$ Department of Biopharmacy, ${ }^{2}$ Department of Molecular Cell Biology, Graduate School of Pharmaceutical Sciences, Chiba \\ University, Inohana 1-8-1, Chuo-ku, Chiba 260-8675, Japan, ${ }^{3}$ Department of Health-Related Informatics, ${ }^{4}$ Department of \\ Pharmacognosy, Faculty of Pharmacy, Silpakorn University, Nakhon Pathom 73000 Thailand, ${ }^{5}$ Department of Natural Products \\ Chemistry, Graduate School of Pharmaceutical Sciences, Chiba University, Inohana 1-8-1, Chuo-ku, Chiba 260-8675, Japan
}

*For correspondence: Email: apirakaramwong_a@su.ac.th; Tel: +66-3425-5800; Fax: +66-3425-5801

\begin{abstract}
Purpose: To investigate the in vitro anti-proliferative effect and mechanism of action of Moringa oleifera Lam. leaf extract on human colon carcinoma HCT116 cell line.

Methods: M. oleifera leaves were extracted with methanol. It was fractionated by Sephadex LH-20 column chromatography. Several fractions were identified by thin layer chromatography (TLC), proton nuclear magnetic resonance $\left({ }^{1} H\right.$ NMR) and mass spectrometry (MS). The growth inhibitory activity and mechanism of action of the extracts in HCT116 colon cancer cells were investigated by 3-(4, 5dimethylthiazolyl-2)-2,5-diphenyltetrazolium bromide (MTT) assay and Western blotting.

Results: Successive fractions from M. oleifera leaf crude extracts by column chromatography were combined into four pooled batches (MOL1 - MOL4) according to their absorbance at $260 \mathrm{~nm}$ and TLC pattern. MOL2 and MOL3 contain astragalin and isoquercetin, respectively. The results from MTT assay indicated that cell proliferation was significantly $(p<0.05)$ inhibited in a concentration-dependent fashion, especially by MOL2, MOL3 and MOL4. MOL2 and MOL3 exhibited a stronger cell growth inhibition than their major ingredients. The anti-proliferative activity of MOL2 - MOL4 in HCT116 colon cancer cells was mediated by downregulation of ERK1/2 phosphorylation.

Conclusion: M. oleifera leaf extract has a strong anti-proliferative activity which is exerted by decreasing ERK1/2 phosphorylation. Thus, the extract has a potential for use in cancer chemoprevention.
\end{abstract}

Keywords: Moringa oleifera, Anti-proliferation, Colon cancer, AKT, ERK1/2 phosphorylation, Chemoprevention

Tropical Journal of Pharmaceutical Research is indexed by Science Citation Index (SciSearch), Scopus, International Pharmaceutical Abstract, Chemical Abstracts, Embase, Index Copernicus, EBSCO, African Index Medicus, JournalSeek, Journal Citation Reports/Science Edition, Directory of Open Access Journals (DOAJ), African Journal Online, Bioline International, Open-J-Gate and Pharmacy Abstracts

\section{INTRODUCTION}

Cancer is one of the leading diseases that results in hundreds of thousand deaths among Thais [13]. Many of the naturally derived anti-cancer drugs successfully became current drugs such as placitaxel, vincristine, and vinblastine. Several wild edible plant species in Thailand have played a prominent role in traditional medicine [4,5]. Moringa oleifera Lam. ( $M$. oleifera) is one of the most common plant found in Southeast Asia that has been widely used [6]. It is also a valuable 
plant because it is rich in vitamins, protein, carbohydrate, fatty acid, fiber and phytochemical components. The phytochemical components present in $M$. oleifera such as glycosides, alkaloids, flavonoids and phenolics are thought to have anti-oxidant and anti-cancer effects [7]. Each part of $M$. oleifera showed different effects on cancer cells [6,8-10]. Moringa root extracts inhibit epithelial ovarian cancer growth [11]. Extracts of $M$. oleifera leaves have been found to elicit anti-oxidant, anti-inflammatory, antibacterial and anti-fungal activities [12,13]. Moreover, $M$. oleifera leaf extracts inhibit human epidermal carcinoma (KB) cell growth analyzed using 3-(4,5-dimethylthiazol-2-yl)-2,5-diphenytetrazolium bromide (MTT) assay [14].

Recently, astragalin, isoquercetin and cryptochlorogenic acid were discovered to be major active components in $M$. oleifera leaf extract [15]. Both astragalin and isoquercetin have been shown to possess anti-oxidant and anti-inflammatory activities [16,17]. Isoquercetin has been studied and found as a major bioactive component in St. John's wort or Klamathweed (Hypericum perforatum L.) [18]. Furthermore, isoquercetin and astragalin are present in vegetables and fruits such as broccoli, onions, cherries, apples [19].

The major cellular functions known to be mediated by mitogen-activated protein kinases (MAPKs) are cell differentiation and transformation, cell proliferation, cell death and survival. MAPK proteins are serine-threonine kinases that include extracellular signal-regulated kinase (ERK), p38, and c-Jun NH2-terminal kinase. The PI3K/AKT and RAS/RAF/MEK/ERK signaling pathways are frequently mutationally activated in human cancer. AKT and ERK signaling pathways have been shown to coregulate several proteins promoting cancer cell survival and tumor growth [20]. Thus, the direct inhibition of AKT and ERK signaling pathways may provide a potential strategy for cancer therapy.

A previous study showed that bioactive fractions from column chromatography separation of $M$. oleifera leaf extract exhibit apoptotic induction activity in HCT 116 colon cancer cells [21]. However, the bioactive compounds from $M$. oleifera leaves have not been clarified.

The present investigation was undertaken to identify the phytochemical compounds from the bioactive fractions and to elucidate the mechanism that may be responsible for the antiproliferative activity.

\section{EXPERIMENTAL}

\section{Plant material and extraction}

Fresh M. oleifera Lam. leaves were collected during January 2012 - December 2013 from Amphoe Mueng, Nakhon Pathom, Thailand. Leaves were cleaned and subsequently dried at $50-60{ }^{\circ} \mathrm{C}$ for 2 - 3 days. The dried leaves were blended by homogenization and extracted in 100 \% methanol for 3 days using a Soxhlet extractor. Alcohol solvent was completely removed from total extraction solution by using an evaporator. The crude extracts were kept in a light protected glass ware at $<4^{\circ} \mathrm{C}$ until used.

\section{Column chromatography on Sephadex LH-20}

The dried crude extract of $M$. oleifera leaves was dissolved in $70 \%(\mathrm{v} / \mathrm{v})$ ethanol at $1 \mathrm{mg} / \mathrm{mL}$ and then filtered with $0.45 \mu \mathrm{m}$ filter membranes (Merck Millipore, Bedford, MA, USA) immediately before use. The fractionation of crude extract was conducted by size exclusion chromatography as described previously [21]. Briefly, the extract was separated into fractions with $2.5 \times 37.5 \mathrm{~cm}$ glass chromatography column (Bio-Rad Laboratories, Richmond, CA, USA) filled with expanded Sephadex LH-20 gel particles (10 - $25 \mu \mathrm{m}$; GE Healthcare, Waukesha, WI, USA) in $70 \%(\mathrm{v} / \mathrm{v})$ ethanol. The column was eluted with $70 \%(\mathrm{v} / \mathrm{v})$ ethanol. Collected fraction of $5 \mathrm{~mL}$ each was monitored by SmartSpec ${ }^{\mathrm{TM}}$ 3000 spectrophotometer $\left(\lambda_{\max }=260 \mathrm{~nm}\right.$; Bio-Rad Laboratories, Richmond, CA, USA). Based on spectral readings, four pooled, combined, fractions (pf1-pf4) were collected. The four combined fractions were evaporated and freezedried. Then, they were stored under refrigeration $\left(-20^{\circ} \mathrm{C}\right)$ and in a dark container.

\section{General procedure}

Optical rotations were measured with a JASCOP-1020 polarimeter (Tokyo, Japan). MS was measured on a JEOL spectrometer (JEOL, Tokyo, Japan). ${ }^{1} \mathrm{H}$ NMR spectra were recorded on an ECA 600 spectrometer (JEOL, Tokyo, Japan) with deuterated solvent. Silica gel presqualene (PSQ) 100B or ODS Chromatorex (Fuji Sylisia, Kasugai, Japan) or Sephadex LH-20 (GE Healthcare Waukesha, WI, USA) were used to carry out column chromatography. Thin layer chromatography (TLC) was done with glass precoated ODS RP18 $\mathrm{F}_{254}$ plates (Merck, Darmstadt, Germany), developing with gradient methanol- $\mathrm{H}_{2} \mathrm{O} \quad(40: 60-80: 20)$. Spots were detected using UV absorbance at 254 and 365 $\mathrm{nm}$ and by spraying with $50 \% \mathrm{H}_{2} \mathrm{SO}_{4}$, then, the 
plate was heated at $90-100^{\circ} \mathrm{C}$ for at least 2 - 3 $\min$.

\section{Extraction and isolation}

Dried methanol extract of $M$. oleifera leaves was subjected to gel filtration on Sephadex LH-20 with four pooled fractions (MOL1 - MOL4) collected. The bioactive fractions, MOL2 and MOL3 were resuspended in methanol and then subjected to octadecylsilyl (ODS) column with different mobile phases. MOL2 was eluted with a gradient mixture of $0-100 \%$ methanol in $\mathrm{H}_{2} \mathrm{O}$ while the MOL3 was eluted with a gradient mixture of $30-100 \%$ methanol in $\mathrm{H}_{2} \mathrm{O}$. The dried MOL2 (40 mg) was eluted, collected and then analyzed by TLC, giving 38 fractions which were pooled into sixteen fractions (F1 - F16) based on the TLC patterns. Fraction F6, a yellow color spot on TLC plate, was concentrated using a rotary evaporator, yielding approximately 2.6 $\mathrm{mg}$ of dried extract. F6 (2.6 mg) was further separated by gel filtration, Sephadex LH-20 column, eluted with $80 \%$ methanol and then analyzed by TLC. Based on the TLC patterns, the eluted subfractions were combined into thirteen subfractions (sf 1 - sf13). The sf13 $(0.9$ $\mathrm{mg}$, compound $\mathrm{A}$ ) was identified using ${ }^{1} \mathrm{H}$ NMR and MS. The dried MOL3 $(10 \mathrm{mg})$ was subjected to ODS column and eluted with similar procedures. The collected eluates were monitored using TLC to obtain 29 fractions (F1 F29). F9 (1 mg, compound B) with a yellow color spot on TLC plate was identified using ${ }^{1} \mathrm{H}$ NMR. The scheme of isolation is shown in Figure 1. The isolated pure compounds were identified by comparing their ${ }^{1} \mathrm{H}$ NMR and MS with published data.

\section{Cell culture}

Human colorectal carcinoma cells (HCT 116) were kindly provided by collaborators. The cells were propagated in Dulbecco's Modified Eagle Medium (DMEM medium (Gibco, Carlsbad, CA, USA) supplemented with $10 \%$ heat-inactivated fetal bovine serum (FBS), $100 \mathrm{U} / \mathrm{mL}$ penicillin, and $100 \mathrm{mg} / \mathrm{mL}$ streptomycin (Sigma). Cells were cultured in a humidified $\mathrm{CO}_{2}$ incubator at 37 ${ }^{\circ} \mathrm{C}$ with $5 \% \mathrm{CO}_{2} /$ air. Cells were assayed during the exponential phase of growth.

\section{Cell proliferation assay using tetrazolium salt (MTT)}

Cell proliferation was measured by MTT assay (Sigma-Aldrich). Briefly, cells $\left(1.2 \times 10^{4}\right.$ cells) were seeded in a 96-well flat-bottomed microplate in $100 \mu \mathrm{L}$ medium overnight before treatment.

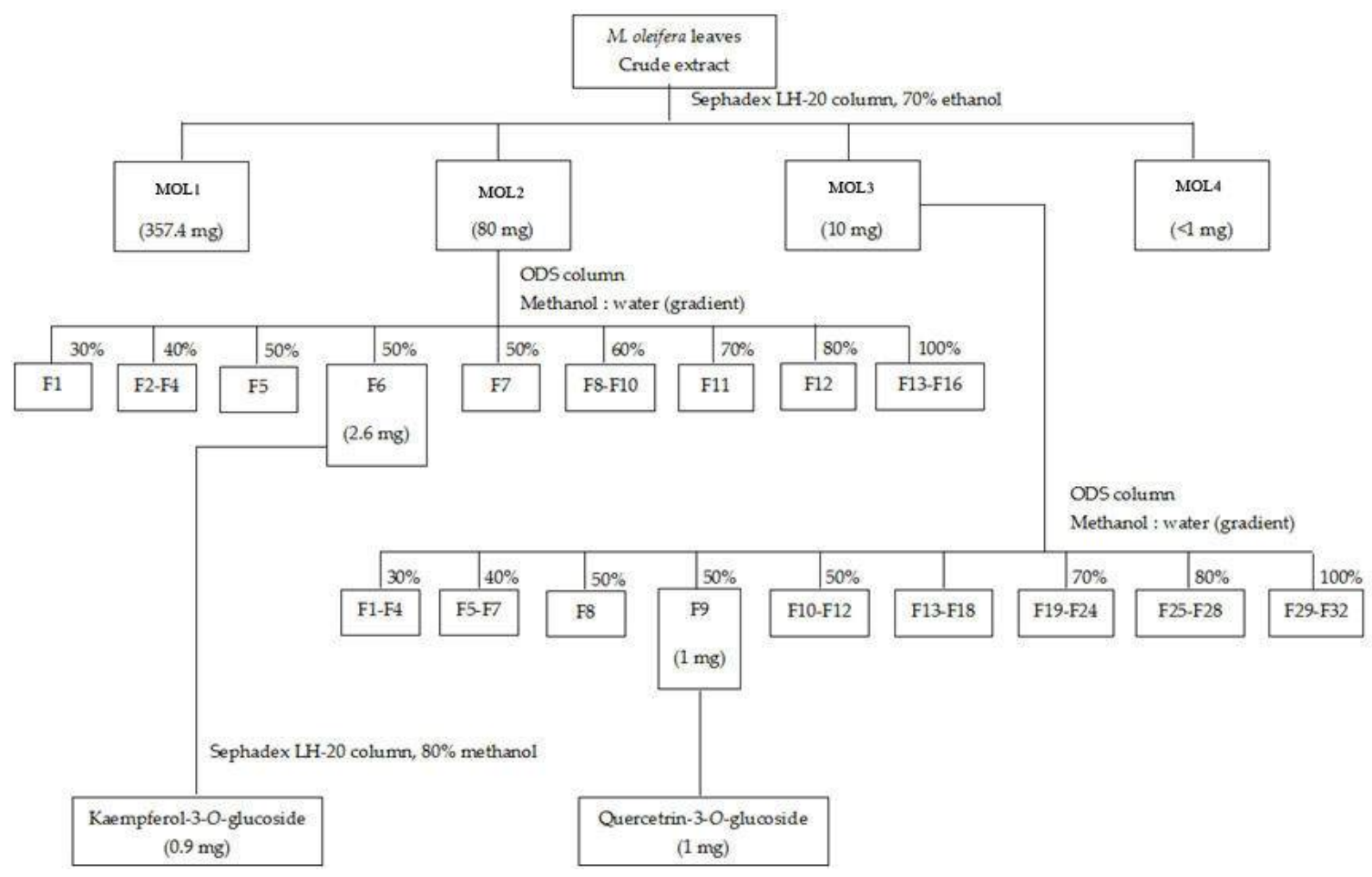

Figure 1: Separation scheme of M. oleifera leaf extract with gel filtration on Sephadex LH-20 after getting four pooled fractions 
After $24 \mathrm{~h}$, the media were removed and replaced with fresh complete medium. Cells were exposed to graded concentrations of test compounds (4 - 5 dilutions in triplicate; MOL1, MOL2, MOL3, MOL4, astragalin, and isoquercetin) for 24 and 48 h. $0.5 \%$ DMSOtreated cells was used as a negative control. Both astragalin and isoquercetin were obtained from Sigma-Aldrich. After the incubation period, each well was washed with phosphate-buffered saline (PBS) and replaced with $1 \mathrm{mg} / \mathrm{mL}$ MTT for $4 \mathrm{~h}$ incubation. The resulting crystals produced from the MTT assay was dissolved in $100 \mu \mathrm{L}$ of $100 \%$ DMSO and quantified at $550 \mathrm{~nm}$ using a microplate reader (Model No; AOPUS01 and A153601; A Packard bioscience company). The proportion of cell viability was calculated as previously described [14].

\section{Cell extraction and western blotting}

HCT116 cells were plated at a density of $1 \times 10^{5}$ cells/mL onto a 6-well plate and incubated overnight. Varying concentrations of the $M$. oleifera pooled fractions were added into the cells for $48 \mathrm{~h}$ in triplicate cultures, compared with positive and negative controls. After treatment with the samples, cells were washed with PBS, $\mathrm{pH} 7.4$ and lysed with lysis buffer (with $1 \mathrm{mM}$ $\mathrm{Na}_{3} \mathrm{VO}_{4}$ and $1 \mathrm{mM} \mathrm{NaF}$ inhibitor) on ice for 15 $\mathrm{min}$. Cell lysates were centrifuged at $13,000 \mathrm{~g}$ for $10 \mathrm{~min}$ at $4{ }^{\circ} \mathrm{C}$, and protein concentrations of supernatants were estimated by Bradford protein assay. Equivalent amounts of total cellular proteins $(5-25 \mu \mathrm{g})$ were separated by $8-12 \%$ SDS-PAGE. Each protein sample was added with sample loading buffer, boiled for $5 \mathrm{~min}$ and kept on ice immediately prior to electrophoresis through a $8-12 \%$ SDS-PAGE at 110 volts for $90 \mathrm{~min}$. Proteins were then transferred onto PVDF membranes. The process was carried out for $1 \mathrm{~h}$ on ice. For immunodetection of the proteins, membranes were blocked in $5 \%$ BSA in TBS-T buffer for $1 \mathrm{~h}$. Probing of PVDF membranes with primary antibodies (pERK1/2 polyclonal antibody \#9101, Akt antibody \#9272 or p38 MAPK antibody \#9212) at $4{ }^{\circ} \mathrm{C}$ overnight and horseradish peroxidase-conjugated secondary antibodies was performed, and signals were detected by enhanced chemiluminescence (ECL). All primary antibodies were purchased from Cell Signaling Technology. The chemiluminescence reagent was poured into the membrane and incubated for 1 - $5 \mathrm{~min}$ at room temperature and then excess chemiluminescence reagent was removed. The membrane was placed and covered with plastic wrap. The imaging film was put on top of the membrane for 5 - 10 min depending on the signal of the protein. The film was developed and analyzed with Image ${ }^{\circledR}$ software.

\section{Statistical analysis}

All experimental measurements were tested in triplicate. The results are expressed as mean \pm standard deviation (SD). Statistical analysis of data was evaluated using one-way analysis of variance (ANOVA). Significance level was set at $p<0.05$.

\section{RESULTS}

\section{Anti-proliferative activity}

Our preliminary results suggested that the crude extract from $M$. oleifera leaves shows inhibitory effect on cell growth in HCT 116 cells. The crude extracts from $M$. oleifera leaves were separated by size exclusion chromatography with Sephadex LH-20 as described previously [21]. The pooled fractions, MOL1 - MOL4, from the crude extract, were assessed against HCT 116 colon cells for anti-proliferative activity in $24 \mathrm{~h}$ (Figure 2a, 2b) and $48 \mathrm{~h}$ (Figure 2c, 2d) using an MTT assay. After 24 and $48 \mathrm{~h}$ treatment with individual pooled fraction, it was shown that HCT 116 cell growth was significantly inhibited in a concentration-dependent fashion, especially when treated with MOL2, MOL3, and MOL4.

\section{MOL2 and MOL3 from M. oleifera leaf extract}

The bioactive MOL2 and MOL3 were subjected to further isolation and identification analysis due to their drastic anti-proliferative activity, while MOL4 was not done because of recovery yield limit. Compound A from MOL2 and B from MOL3 were got as a yellow amorphous powder. The ${ }^{1} \mathrm{H}$ NMR spectra of $A$ and $B$ showed the characteristic signals of flavonoid glycosides. The molecular formula of $A$ and $B$ were indicated as $\mathrm{C}_{21} \mathrm{H}_{20} \mathrm{O}_{11}$ and $\mathrm{C}_{21} \mathrm{H}_{20} \mathrm{O}_{12}$, respectively by $\mathrm{MS}$, which gave molecular ion peak at $\mathrm{m} / \mathrm{z} 447$ and $463[\mathrm{M}-\mathrm{H}]-$-. In addition to the mass of compound $A$ and $B{ }^{1} H$ NMR spectra showed signals corresponding to a sugar moiety. Thus, the structure of $\mathrm{A}$ and $\mathrm{B}$ was determined as kaempferol 3-O-glucoside (astragalin) and quercetin 3-O-glucoside (isoquercetin), respectively.

Astragalin: yellow amorphous powder, Molecular formula: $\mathrm{C}_{21} \mathrm{H}_{20} \mathrm{O}_{11}$. LC-MS: m/z 447 $[\mathrm{M}-\mathrm{H}]^{-1}{ }^{1} \mathrm{H}$ NMR $\left(600 \mathrm{MHz}, \mathrm{CO}_{3} \mathrm{OD}\right): \delta \mathrm{ppm} 7.92$ (d, J=8.72, 2H, H-2', 6'), 6.75 (d, J=8.98, 2H, H$\left.3^{\prime}, 5^{\prime}\right), 6.21$ (d, J=2.05, 1H, H-8), 6.03 (d, 2.05, $1 \mathrm{H}, \mathrm{H}-6), 5.08(\mathrm{~d}, \mathrm{~J}=7.18,1 \mathrm{H}, \mathrm{H}-1$ " of $\mathrm{Glc}$ ) [22]. 

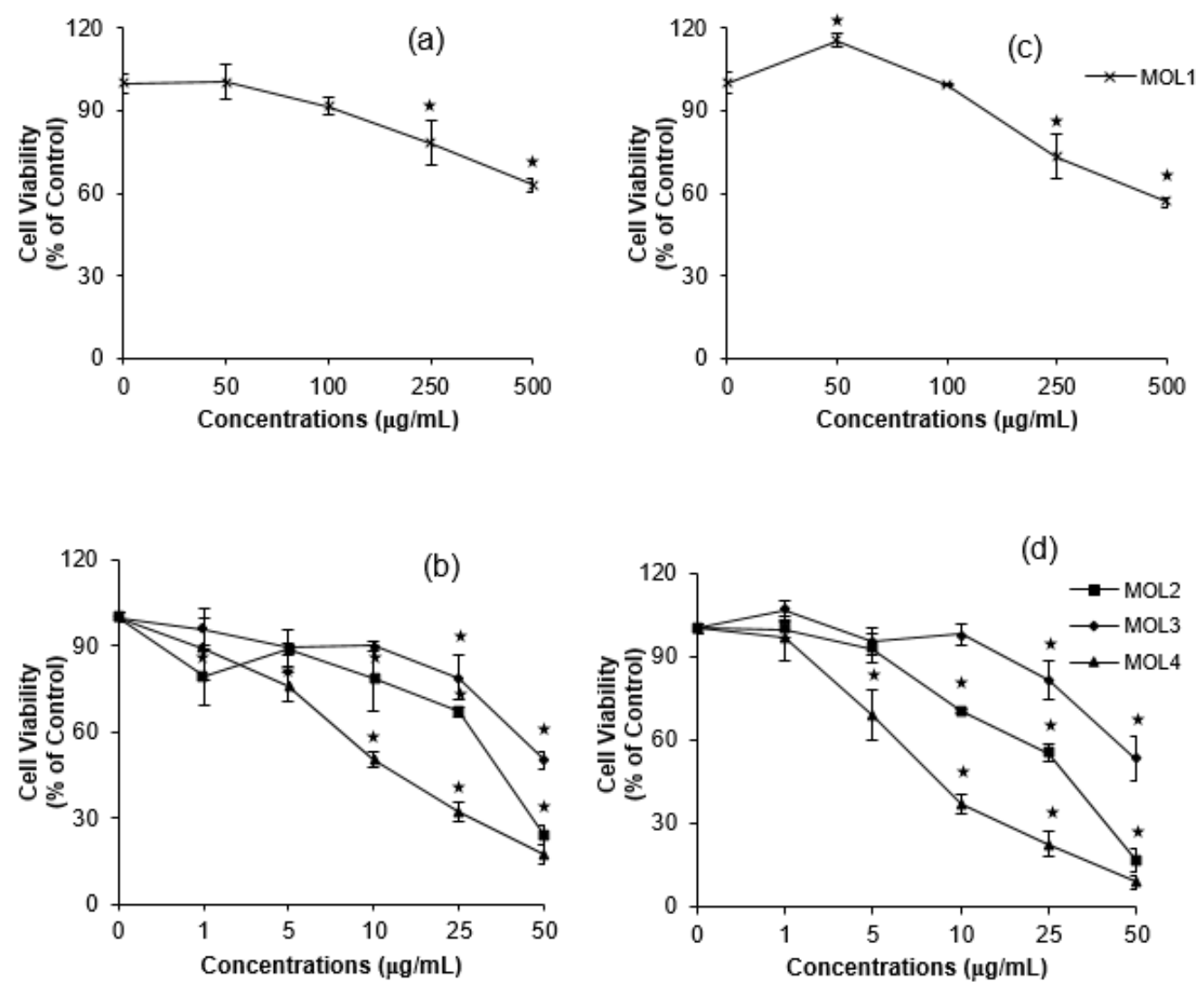

Figure 2: The anti-proliferative activity of each pooled fraction (MOL1-MOL4) on HCT116 cells at different concentrations for $24 \mathrm{~h}(\mathrm{a}, \mathrm{b})$ and $48 \mathrm{~h}(\mathrm{c}, \mathrm{d})$. Each value represents the mean \pm SD of the triplicate of cultures, ${ }^{*} p<0.05$, significantly different from the negative control treated with $0.5 \%$ of DMSO

Table 1: Toxicity of each pooled fraction (MOL1 - MOL4) in HCT116 and NHF cells at $24 \mathrm{~h}$ and $48 \mathrm{~h}$

\begin{tabular}{|c|c|c|c|c|}
\hline \multirow{3}{*}{ Sample } & \multicolumn{4}{|c|}{$\mathrm{IC}_{40}$ (approx, $\left.\mu \mathrm{g} / \mathrm{mL}\right)$} \\
\hline & \multicolumn{2}{|c|}{$24 \mathrm{~h}$} & \multicolumn{2}{|c|}{$48 \mathrm{~h}$} \\
\hline & HCT116 & NHF & HCT116 & NHF \\
\hline $\mathrm{MOL1}$ & 517.54 & $>500$ & 462.60 & $>500$ \\
\hline MOL2 & 25.84 & 106.19 & 19.02 & 51.52 \\
\hline MOL3 & 41.38 & 52.50 & 44.02 & 39.20 \\
\hline MOL4 & 9.50 & 17.04 & 5.04 & 17.70 \\
\hline Astragalin & $>500$ & NA & $>500$ & NA \\
\hline Isoquercetin & 68.52 & NA & 5.41 & NA \\
\hline
\end{tabular}

$\mathrm{NA}=$ not determined

Isoquercetin: yellow amorphous powder, Molecular formula: $\mathrm{C}_{21} \mathrm{H}_{20} \mathrm{O}_{12}$, LC-MS: $\mathrm{m} / \mathrm{z} 463$ $[\mathrm{M}-\mathrm{H}]$. ${ }^{1} \mathrm{H}$ NMR (600 MHz, CO $\left.\mathrm{CO}_{3} \mathrm{OD}\right) \delta \mathrm{ppm} 7.70$ (d, J=2.31, 1H, H-2'), 7.58 (dd, J=2.31, 8.46, 1H, $\left.H-6^{\prime}\right), 6.86$ (d, J=8.46, $\left.1 \mathrm{H}, \mathrm{H}-5^{\prime}\right), 6.35$ (d, $J=2.05$, $1 \mathrm{H}, \mathrm{H}-8), 6.17(\mathrm{~d}, \mathrm{~J}=2.05,1 \mathrm{H}, \mathrm{H}-6), 5.23(\mathrm{~d}$, $J=7.69,1 \mathrm{H}, \mathrm{H}-1$ " of $\mathrm{Glc}$ ).

The peaks assigned in ${ }^{1} \mathrm{H}$ NMR corresponded to previous studies $[23,24]$.

\section{Cell proliferation inhibitory effect}

In order to confirm that the anti-proliferative activity of $M$. oleifera leaf extracts may come from their major compounds and may have a different effect on normal and cancer cells, the determination of cytotoxicity in normal human fibroblast (NHF) and HCT116 cells was done at 24 and $48 \mathrm{~h}$ (Table 1). Because insufficient protein lysate obtained when $\mathrm{IC}_{50}$ was used in the cell, $I_{40}$ was used instead in Western blot analyses.

The results showed that the cytotoxic effect of $M$. oleifera leaf extracts in HCT116 cells was higher than that in NHF cells. Although, MOL2 contained astragalin, the cytotoxicity of MOL2 was likely higher than its major component. In contrast, MOL3 contained isoquercetin, the 
cytotoxicity of MOL3 was higher than its major component in $24 \mathrm{~h}$ of treatment but less than that in $48 \mathrm{~h}$. Moreover, the cytotoxicity associated with $M$. oleifera leaf extracts in HCT116 was higher than that in the NHF normal cell line, demonstrating that normal cells are more resistant to the extract than cancer cells.

To clarify the anti-proliferation mechanism of $M$. oleifera leaf extracts in $48 \mathrm{~h}$ treated HCT116 cells, the protein expression of ERK, AKT, and p38 MAPK was further examined using the total
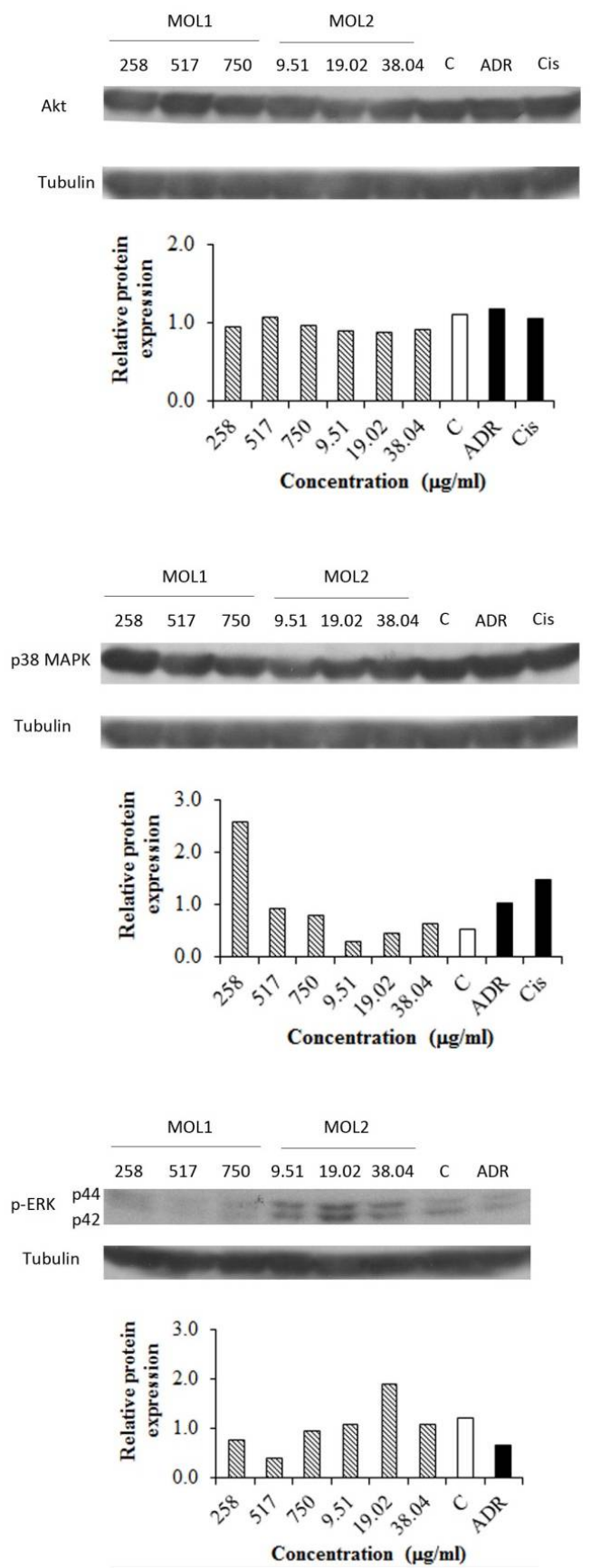

Figure 3: Effect of each pooled fraction (MOL1-MOL4) in HCT116 cells at $48 \mathrm{~h}$ of treatment on AKT (upper panel), p38 MAPK (middle panel) and phospho-ERK1/2 (lower panel) expression using western blot and Image ${ }^{\circledR}$ software analysis. Tubulin was used as loading control. Adriamycin $(0.1 \mu \mathrm{g} / \mathrm{mL})$ and cisplatin $(125 \mu \mathrm{g} / \mathrm{mL})$ were used as positive control 


\section{DISCUSSION}

In Thailand, colon cancer is considered the most common cancer in men and the third in women [3]. The development and invasion process of cancers including colon cancer is correlated with $\mathrm{PISK} / \mathrm{AKT}$ and RAS/RAF/MEK/ERK pathways [20]. The concomitant activation of AKT and ERK pathway leads to enhanced cancer progression and metastasis. Chemoprevention by natural products to inhibit or prevent tumorigenesis is a new strategy for cancer control [25]. M. oleifera has long been used in Thai cuisine. Its leaves are a good source of nutrients and bioactive compounds [26]. There are many reports suggesting that $M$. oleifera leaves possess anticancer properties with their anti-oxidant activity $[8,9,11,14]$ or by down-regulating NF-kB [27].

The present study focused on anti-proliferation activity and mechanism of action of four pooled fractions from $M$. oleifera leaf extract against HCT116 colon cancer cell line. In accordance with previous study, this method of extraction i.e. column chromatography is also effective in separation of major flavonoid glycosides, astragalin, and isoquercetin in $M$. oleifera leaves, [15]. Both astragalin and isoquercetin are shown to have antioxidant and anti-proliferative activities [28]. Therefore, the presence of astragalin and isoquercetin in $M$. oleifera leaf may be responsible for the promising property in chemoprevention. That was suggested by a significant suppression of HCT116 cell proliferation with the pooled fractions, especially MOL2-MOL4.

As mentioned above, ERK and AKT pathways are important for proliferation and survival of cancer cells. Furthermore, there are few studies on the effect of $M$. oleifera leaf on these pathways in colorectal cancer. The results show that the phosphorylation of ERK $1 / 2$ was dramatically inhibited by $M$. oleifera leaf fractions, along with a small reduction in AKT expression, but not p38 MAPK.

Taken together, the results show that $M$. oleifera leaf extract inhibits HCT116 cell proliferation through downregulation of ERK $1 / 2$ phosphorylation.

\section{CONCLUSION}

Column chromatography has successfully been used for the separation of two flavonoid glycosides, astragalin, and isoquercetin, from bioactive fractions of $M$. oleifera leaf extracts. The bioactive fractions exhibit anti-proliferative activity against colon cancer cells that is different from standard compounds. A likely mechanism of action of the anti-proliferative activity is pERK $1 / 2$ downregulation. Further studies are necessary to investigate the precise components as well as other molecular mechanisms of action.

\section{DECLARATIONS}

\section{Acknowledgement}

The authors thank Dr Chatchai Chinpaisan for his kind suggestion in the manuscript preparation. This study was supported in part by Excellent International Student Scholarship between Chiba University/Silpakorn University, Silpakorn University Research and Development Institute (Grant no. SURDI 58/01/12), Thailand Research Fund (TRF) (no. MRG5680119), and Grants-in-Aid for Scientific Research (NY, 15K07922) from Japanese Ministry of Education, Culture, Sports, Science and Technology.

\section{Conflict of Interest}

No conflict of interest associated with this work.

\section{Contribution of Authors}

The authors declare that this work was done by the authors named in this article and all liabilities pertaining to claims relating to the content of this article will be borne by them.

\section{Open Access}

This is an Open Access article that uses a funding model which does not charge readers or their institutions for access and distributed under the terms of the Creative Commons Attribution License (http://creativecommons.org/licenses/by 14.0) and the Budapest Open Access Initiative (http://www.budapestopenaccessinitiative.org/rea d), which permit unrestricted use, distribution, and reproduction in any medium, provided the original work is properly credited.

\section{REFERENCES}

1. Dobrossy L. Cancer mortality in central-eastern Europe: facts behind the figures. Lancet Oncol 2002; 3: 374-381.

2. Neumann J, Boerries M, Köhler R, Giaisi M, Krammer $\mathrm{PH}$, Busch $\mathrm{H}$, Li-Weber $M$. The natural anticancer compound rocaglamide selectively inhibits the G1-Sphase transition in cancer cells through the ATM/ATRmediated Chk1/2 cell cycle checkpoints. Int J Cancer 2014; 15(134): 1991-2002.

3. Information Technology Division. National Cancer Institute, B. Cancer report year 2011, National Cancer 
Institute (NCl): Bangkok, Thailand, 2011.

4. Chanwitheesuk A, Teerawutgulrag A, Rakariyatham $N$. Screening of antioxidant activity and antioxidant compounds of some edible plants of Thailand. Food Chem 2005; 92: 491-497.

5. Manosroi J, Dhumtanom P, Monosroi A. Anti-proliferative activity of essential oil extracted from Thai medicinal plants on KB and P388 cell lines. Cancer Lett 2006; 235: 114-120.

6. Anwar F, Latif S, Ashraf M, Gilani AH. Moringa oleifera: A food plant with multiple medicinal uses. Phytother Res 2007; 21: 17-25.

7. Zhou Jr Yu L, Zhong Y, Blackburn GL. Soy phytochemicals and tea bioactive components synergistically inhibit androgen-sensitive human prostate tumors in mice. J Nutr 2003; 133: 516-521.

8. Budda $S$, Butryee C, Tuntipopipat $S$, Rungsipipat A, Wangnaithum S, Lee JS, Kupradinun P. Suppressive effects of Moringa oleifera Lam pod against mouse colon carcinogenesis induced by azoxymethane and dextran sodium sulfate. Asian Pac J Cancer Prev 2011; 12: 3221-3228.

9. Pamok S, Saenphet S, Vinitketkumnuem U, Saenphet $K$. Anti-Proliferation effect of Moringa oleifera and Psenderanthera palatiferum extracts on the colon cancer cell. J Med Plants Res 2012; 6: 139-145.

10. Guevara $A P$, Vargas $C$, Sakurai $H$, Fujiwara $Y$, Hashimoto K, Maoka T, Kozuka M, Ito $Y$, Tokuda $H$, Nishino $H$. An antitumor promoter from Moringa oleifera Lam. Mutat Res 1999; 6: 181-188.

11. Bose CK. Possible role of Moringa oleifera Lam. root in epithelial ovarian cancer. Med Gen Med 2007; 9: 26.

12. Peixoto JRO, Silva GC, Costa RA, Fontenelle JLS, Vieira GHF, Filho $A A F$, Vieira RHSF. In vitro antibacterial effect of aqueous and ethanolic Moringa leaf extracts. Asian Pac J Trop Med 2011; 4: 201-204.

13. Chuang P, Lee C, Chou J, Murugan M, Shieh B, Chen H. Anti-fungal activity of crude extracts and essential oil of Moringa oleifera Lam. Bioresour Technol 2007; 98: 232236.

14. Sreelatha S, Jeyachitra A, Padma PR. Antiproliferation and induction of apoptosis by Moringa oleifera leaf extract on human cancer cells. Food Chem Toxicol 2011; 49: 1270-1275.

15. Vongsak B, Sithisarn $P$, Gritsanapan W. Simultaneous determination of crypto-chlorogenic acid, isoquercetin, and astragalin contents in Moringa oleifera leaf extracts by TLC-densitometric method. Evid Based Complement Alternat Med 2013; 917609. doi: 10.1155/2013/917609. Epub 2013 Feb 25.

16. Cho IH, Gong JH, Kang MK, Lee EJ, Park JH, Park SJ, Kang $\mathrm{YH}$. Astragalin inhibits airway eotaxin-1 induction and epithelial apoptosis through modulating oxidative stress-responsive MAPK signaling. BMC Pulm Med 2014; 29: 122. doi: 10.1186/1471-2466-14-122.

17. Vongsak B, Mangmool S, Gritsanapan W. Antioxidant activity and induction of mRNA expressions of antioxidant enzymes in HEK-293 cells of Moringa oleifera leaf extract. Planta Med 2015; 81: 1084-1089.

18. Valentová $K$, Vrba J, Banciřrová M, Ulrichová J, Křen V. Isoquercetin: pharmacology, toxicology, and metabolism. Food Chem Toxicol 2014; 68: 267-282.

19. Huang WY, Cai YZ, Zhang Y. Natural phenolic compounds from medicinal herbs and dietary plants: potential use for cancer prevention. Nutr Cancer 2010; 62: 1-20.

20. Ye $Q$, She $Q B$. Integration of $A K T$ and ERK Signaling Pathways in Cancer: Biological and Therapeutic Implications. J Pharmacol Clin Toxicol 2013; 1(2): 1009.

21. Tragulpakseerojn J, Yuki $R$, Honda $T$, Morii $M$, Apirakaramwong A, Yamaguchi $N$, Pamonsinlapatham $P$, Yamaguchi $N$. Apoptotic activities of the extract from Moringa oleifera leaves on human HCT 116 colon cancer cells. Fund Toxicol Sci 2014; 1: 143-149.

22. Robard K. Strategies for the determination of bioactive phenols in plants, fruit and vegetables. $J$ Chromatogr $A$ 2003; 1000: 657-691.

23. Kazuma K, Noda N, Suzuki M. Flavonoid composition related to petal color in different lines of Clitoria ternatea. Phytochem 2003; 64: 1133-1139.

24. Kazuma K, Noda N, Suzuki M. Malonylated flavonol glycosides from the petals of Clitoria ternatea. Phytochem 2003; 62: 229-237.

25. Khoogar R, Kim BC, Morris J, Wargovich MJ. Chemoprevention in gastrointestinal physiology and disease. Targeting the progression of cancer with natural products: a focus on gastrointestinal cancer. Am J Physiol Gastrointest Liver Physiol 2016; 310(9): G629G644.

26. Leone A, Fiorillo $G$, Criscuoli $F$, Ravasenghi $S$, Santagostini L, Fico G, Spadafranca A, Battezzati A, Schiraldi A, Pozzi F, di Lello S, Filippini S, Bertoli S. Nutritional characterization and phenolic profiling of Moringa oleifera Leaves grown in Chad, Sahrawi Refugee Camps, and Haiti. Int J Mol Sci 2015; 16(8): 18923-18937.

27. Berkovich L, Earon G, Ron I, Rimmon A, Vexler A, LevAri $S$. Moringa oleifera aqueous leaf extract downregulates nuclear factor-kappa $B$ and increases cytotoxic effect of chemotherapy in pancreatic cancer cells. BMC Complement Altern Med 2013; 13: 212.

28. Yi J, Wu JG, Wu YB, Peng W. Antioxidant and antiproliferative activities of flavonoids from Bidens pilosa $L$ var radiata Sch Bip. Trop J Pharm Res 2016; 15(2): 341-348. 